\title{
The Effects of Land Use Act on Sustainable Housing Provision in Nigeria: The Lagos State Experience
}

\author{
Ola Aluko \\ Department of Urban \& Regional Planning \\ Faculty of Environmental Sciences \\ University of Lagos \\ Akoka, Lagos
}

Tel: 234-80-2324-0693E-mail: eoaluko@gmail.com, eoaluko@yahoo.com

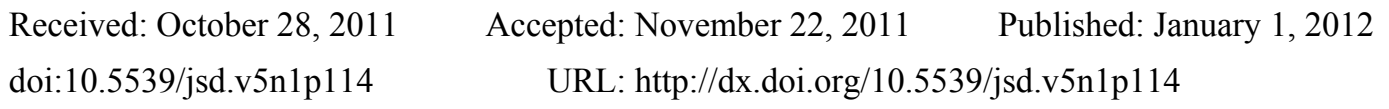

\begin{abstract}
We have watched over the decades the problems encountered in acquisition of land and subsequently in obtaining the approval of certificate of occupancy and housing delivery in Nigeria. In the commencement of the Land Use Act 1978, it was stated that "whereas it is in the public interest that the rights of all Nigerians to the land of Nigeria be asserted and preserved by law". Our concern is not really another criticism against the Act but an in-depth evaluation of how it has achieved its aim if any in the mass provision of housing to the people. That is, where lays the hope of the masses in the current wave of high cost of acquisition of land? It should be noted that one of the cogent reasons why the Act came into existence was because of the nature of trusteeship of land in the past; it was difficult for just anyone to get access to land. Could we now say it is very easy for just anyone to get access to land? Therefore, this research paper critically re-examined in-depth the motives behind the act vis-à-vis the present realities and the implication on housing provision; evaluate the achievements realized so far in terms of implementation since the promulgation of the act and ways to facilitate and sustain housing delivery; and review the areas of bottlenecks and suggest possible ways of ameliorating the identified problems.
\end{abstract}

Keywords: Land use act, Housing provision, Sustainable development

\section{Introduction}

Today, if you buy land in Nigeria and you do not have the Certificate of Occupancy (C of O) from the government, it is not yours, all you have is a lease, that is, you never have a freehold. You cannot even have access to any loan or do anything tangible if you do not have fund of your own, not even the National Housing Fund which was set up by the government to render such assistance. Yet the Certificate of Occupancy is even more difficult than getting the land itself. All efforts by some State Governments especially the Lagos State government to ease the procedure and collection have been described as mere gimmicks. We have heard series of cases where Governors wield their powers to revoke legally acquired rights of occupancy in the interest of the public, whereas it was obvious that they were done on political reasons especially against oppositions. The former President of the federation who was the author of the Act when it was promulgated during his first military administration had to reassure Nigerians on $26^{\text {th }}$ of September 2001 in Abuja that "no government owns land" and that "land belongs to the people". This statement was made when he was condemning the excesses of the Governors. As stated above, since it is a known philosophy that laws are made by men for men and are operated, implemented and enforced by human beings through various legal institutions, our concern is how the Act has helped in the housing scheme.

Several controversies that were created by the Act have been well documented in different reactions and write-ups (Oduniyi, 1981; Megbolugbe, 1983; Udo, 1990; Onibokun, 1985; 1990; Ayeni, 1991; Tobi, 1997; Mabogunje, 2007; 2011; Aluko, 2009; 2010). Mabogunje (2007; 2011) and Aluko (2007; 2009; 2010) dealt excessively on the gory state of affairs about the housing situations in Lagos State in particular and Nigeria in general and how it could be sustained. In this research paper, we try to examine the effects if any, that the Land Use Act has had on the aspect of housing provision in Nigeria. Since one of the major areas of the Act is to control future uses and open new land for the needs of Nigeria's growing population especially in urban areas, yet there is still the outcry of the people to affordable housing provision. In Lagos State the municipalities (local 
governments) have no say in the issue of Certificate of Occupancy as all lands in the State has been declared urban and are all under the control of the governor.

Whereas in the commencement of the Land Use Act 1978 No. 6 on $29^{\text {th }}$ March, 1978, it was stated that "whereas it is in the public interest that the rights of all Nigerians to the land of Nigeria be asserted and preserved by law". And that "... all lands comprised in the territory of each State in the Federation are hereby vested in the Governor of the State..." The Act also provides that "all land in urban areas shall be under the control and management of the Governor of each State". Our concern is not really another criticism of the Act but an in-depth evaluation of how it has achieved its aim if any in the mass provision of housing to the people. That is, where lies the hope of the masses in the current wave of high cost of acquisition of land? It should be noted that one of the cogent reasons why the Act came into existence was because of the nature of trusteeship of land in the past. It was difficult for anyone to get access to land. Could we now say it is very easy for anyone to get access to land?

\section{Justification for the Research Study and Methodology}

We have watched over the decades the problems encountered in acquisition of land and subsequently in obtaining the Certificate of Occupancy. When the prices of housing units (including the low, medium and high cost units) are compared with the millions of people that are in deer need of housing, then it is obvious that we are seriously at crossroads. For instance, the Managing Director of the Federal Mortgage Bank of Nigeria (FMBN) revealed in 2003 that over 100 people have so far benefited from the National Housing Fund (NHF) loan and about 400 people in 2010 since the inception of the scheme over twelve years ago. However, figures from National Housing Fund loans disbursement show that at the end of 1997 only 7 people benefited; 17 people by $1998 ; 221$ by 1999 and 150 by 2000 . This means that as at 2010 , less than 1000 people had benefited from a population of over 150 million. This was essentially due to the fact that most of those who are qualified and possess land do not have the collateral security of Certificate of Occupancy, which is a major condition for the loan. Meanwhile, over 70 percent of population of metropolitan Lagos and even Nigerians live in the informal sector.

The methodology for the research work involved both primary and secondary data collected on previous researches. The primary data relied on questionnaires collected from stakeholders from the ministries involved in the issue of Certificate of Occupancy and provisions of housing and development control in Lagos State. Some notable housing developers were also interviewed on their perception to Land Use Act and how it has aided or affected housing provision. While the secondary data were collected from the various ministries related to housing provisions and the major private housing developers. The data were analysed through the means of simple statistical analyses as tables, graphs and descriptive analyses.

About nine years ago, the Federal Ministry of Works and Housing projected that by the year 2000, eight million units of houses would be needed before housing could be provided for all. This amounted to five million housing units in the urban areas and three million units in the rural areas. This projection had doubled to 16 million housing units by now (2011) from Ministry of Housing and Urban Development. Even the parastatal complained that the Federal Government would need about N16 trillion $(\$ 160 \mathrm{~b})$ then to provide housing for all citizens at a minimum housing unit cost of $\mathrm{N} 200,000(\$ 2,000)$. And with a yearly budget of the country which was about N200 billion (\$2b) in 1999, it would take 80 years to raise N16 trillion. This means that it would be close to the end of the next millennium before the present housing problem could be solved. Now that a minimum housing cost is about N1.5 million $(\$ 9,700)$, and with 2011 budget at N4.4 trillion $(\$ 28.4 \mathrm{~b})$, there is need for about N14 trillion (\$90.3b) for housing alone. With this scenario, the ultimate goal of the National Housing Policy to ensure that all Nigerians own or have access to decent accommodation at affordable cost by the year 2,000 A.D. was dashed and even up till now.

Our concern in this research paper is not to discuss the forgone hope of the unreliable and impossible projection but the way forward for the masses. It is now evident that the housing provision in Nigeria, particularly the low income group featured prominently on paper promises up to the end of the $20^{\text {th }}$ century with no concrete steps taken to enliven the hopes of the masses. The consolation slogan of "housing for all by the year 2000 " has changed to the hard fact of "what Nigerians failed to realize is that housing is a thing that every family would need to provide for itself". Since the era of subsidy is gone and privatization is now the order of the day, this reality has raised a lot of pertinent questions especially on where lies the hope of the masses in housing delivery. Therefore, concerted efforts must quickly be looked into to reconsider viable policies and strategies that will alleviate the sufferings of the masses. Sustainable plans are being focused on for proper housing delivery.

A number of factors are affecting cost of housing, e.g. cost of land, construction costs, cost of housing finance, administration and management cost, et cetera. With these, the aim of this study is to examine all the possible 
land acquisition methods and alternatives in which decent housing accommodation could still be made accessible and at affordable cost to the Nigerian masses who desire good living. The means of achieving the above aim are to re-examine the existing strategies and then propose new ones.

\section{Land Policy}

Ownership of a house starts from the acquisition of a piece of land. That is to say the intending house owner must first of all have access to land. In urban areas access to land is not quite easy and that is why one of the objectives of the Land Use Act is to ensure that land is made available promptly to all those who need it in the interest of the economy. But there is still the big question "how accessible is man to land?"

\subsection{The Land Use Act}

On March $29^{\text {th }} 1978$, about one month after the publications of the Government White Paper on the Land Use panel Report, the Federal Military Government enacted the Land Use Act. Six months later, the Act was incorporated into the new Nigerian Constitution which took effect from October, 1979; as an existing law when the military terminated its 13 year rule of the country. The incorporation of the Land Use Act into the Constitution was aimed at preventing the incoming civilian administration from repealing the Act by a simple majority in the National Assembly. It succeeded in delaying for four years a debate of the bill (tabled in October, 1982) to repeal the Land Use Act; to the annoyance of politicians who had promised the electorate in 1979 that if elected, they would initiate action to abrogate the Land Use Act as soon as the national Assembly convened. The bill which was introduced late in 1982 and was expected to be debated in 1984 was swept away, along with its supporters on December $30^{\text {th }} 1983$ when the Shagari administration was toppled in a military coup. The rest of this paper considers some of the more important provisions of the Land Use Act along with the immediate reactions of the people to the Act in general and to some of the more controversial provisions in particular.

Like most other land policy enactments and land reform legislations, the Land Use Act is intended to achieve a number of political, economic and social objectives. It makes a modest attempt to re-distribute property in land so as achieve a wider measure of social justice and seeks to tackle the economic ills associated with extreme fragmentation of farm land. Its most fundamental provision, however, is that all lands in the territory of each state of Nigeria now vest in the Governor of that state. The basic principles of the Act are, however, identical with the fundamental principles of Nigerian customary land tenure laws, a fact which many people do not appear to appreciate. Under Nigerian customary land law, for instance, individuals have usufructurary, not absolute, rights in land, while the family head or the head of government (Oba, Obi or Emir) is merely the trustee of land in his area of authority. The Land Use Act as already being pointed out is therefore conceptually not new; an observation which equally applies to the Northern Nigeria Land Tenure law of 1962.

\subsection{General Provisions of the Land Use Act}

One of the controversial provisions of the Act is the vesting of all land in the territory of each State in the Governor of that State. For the Southern States this provision implied a revolutionary change in the ownership and control of land, but not so in the Northern states which had operated a similar law since about 1916. Henceforth in the Southern States, the Government replaced the family head, the Oba or any other traditional ruler as the trustee of land.

There are three other general provisions which make up Part 1 of the Act. These are basically administrative regulations dealing respectively with the control and management of land, the designation of urban areas within each state and the applicable law for the interim management of land. Provision is made for a State Land Use and Allocation Committee to advise Governors on any matter connected with the management of urban land, the resettlement of persons displaced when land is compulsorily acquired for public purposes and the determination of disputes over compensation payable for improvements on land. There was also a provision for a second committee called the Land Allocation Advisory Committee for each Local Government Area to advise the relevant Local Government on any matter connected with the management of rural land. Only the Governor may declare any settlement in the state to be an urban area. Since land in urban areas came under the direct control of the Governor, some Local Governments within Ibadan Metropolitan Areas became worried about the possibility of all lands within their jurisdiction coming under the direct control of the Governor.

\subsection{Some of the Presumed Objectives of the Land Use Act Are as Follows}

A. to enable the government to bring under control the use to which land is being put and thus facilitate planning for government projects;

B. to ensure that land is made available promptly to all those who need it in the interest of the economy; 
C. to assist every Nigerian, irrespective of his social status to own a house of his own for the benefit of himself and his family.

However, some aspects of the administration of the Act have become so frustrating that the good intentions of obtaining a certificate of occupancy, grant of consent to assign, grant of consent for a subsequent transaction, with adverse effect on land acquisition and housing delivery.

\subsubsection{Application for a Right of Occupancy}

The problem associated with a Nigerian applying for a right of occupancy was summarized by NNAMANI J.S.C when he said.

"Aspect of the act which in implementation has brought untold hardship includes the provision relating to the issue of certificate of occupancy and grant of consent to alienate; both can take years, and the application is subject to the vagaries of bureaucratic action with demands for survey plans. Interminable fees, documents and a lot of to and fro. These cumbersome procedures already affected economic and business activity and made industrial take off a matter very much in future".

\section{Housing Development in Nigeria}

Having regards to the fact that housing is one of the best indicators of a person's standard of living and of his place in the society, it also serves as a place in which man seeks shelter, comfort, security and dignity among other things. Housing project in Nigeria is the responsibility of both the public and the private sectors.

\subsection{The Public Sector Contributions}

\subsubsection{Present Housing Policy of the Lagos State Government}

The Lagos State Government recognized that its role in the area of housing provision is complex and it is one where policy may conflict with reality. The need for qualitative and quantitative housing whether owned or rented has arisen. The policy of the housing programme for the state government is in full consideration of the number of housing requirement for the state up to year 2000 and after as follow:

i. To ease or reduce acute shortage of accommodation forcing some desperate inhabitants to be living under the overhead bridges.

ii. To provide safe, adequate and affordable accommodation for both the rural and urban dwellers at a rate of at least 2000 units per annum.

iii. To recognize the fact that enough houses of acceptable standard is an instrument for solving problems of public health control over diseases in the environment.

iv. To provide and promote efficient housing delivery system, through the combined, efforts of profit oriented companies, state agency as well as the three tiers of governments in Nigeria with all seriousness short of hopeless political statement.

v. To provide qualitative planned environment that will enhance the quality of life of the inhabitants of Lagos State.

vi. To improve the existing houses, such as slums and blight areas of the state and replace them gradually with better accommodation.

vii. To inculcate a saving culture for housing project into the spending pattern of the citizens.

viii. To give rural areas a befitting face-lift.

ix. To create new towns in selected areas through the participation of private developers like the present Federal Capital Territory, Abuja, Ajoda new town etc.

x. To involve the Local Governments in the provision of low cost houses. (If it is low, it is deemed to be affordable).

\subsection{Operations of Public Housing Agencies in Lagos State}

The housing corporations that are responsible for the execution of the various housing policies as formulated by the state and federal government in Lagos State are the Lagos State Development and Property Corporation (LSDPC) and Federal Housing Authority (FHA) respectively. The activities of the Local Government in property development have been limited to the erection of corner shops and building of commercial complexes. 


\subsubsection{Lagos State Development and Property Corporation (LSDPC)}

The corporate body known as the Lagos State Development and Property Corporation (LSDPC) came into existence through the merger of the Lagos Executive Development Board, Ikeja Area Planning Authority and the Epe Town Planning Authority. With the promulgation of the LSDPC Law No 1 of 1972, the role of the LSDPC in the provision of housing accommodation in the Lagos metropolis became pronounced.

The corporation on its creation inherited all the assets of its predecessors together with their liabilities and responsibilities, and has been operating within the Housing Policy guidance of the Lagos State Government. It is worth saying that the LSDPC is the first Housing Development agency in the country to introduce the sale of flats on mortgage to the public.

The Edict creating the Corporation empowered it under section 4 to carry out the following main functions among others:

i. To acquire, develop, hold, manage, sell, lease or let any property movable or immovable within the State.

ii. To provide and establish a Home-ownership scheme in respect of any housing estate or building owned, constructed and managed by the corporation.

iii. Subject to the provision of the Law to carry out all activities for the purpose of carrying out its functions under the said Law.

Above all, it is vested with the powers to provide and manage residential, commercial and industrial houses throughout the State. The Law also provided for the employment of the necessary professional sub-professional and general personnel to enable it effectively carry out the execution of the functions devolving on it. However, subsequent activities of the State Government necessitated the divestment of some of the LSDPC prescribed functions. Hence the Land Use and Allocation Directorate, New Towns Development Authority, Survey Department and Lagos Building Investment Company (LBIC) were established out of LSDPC.

To date, the corporation has to its credit low, medium and high income estates which are found at various locations. The corporation also engages in the provision of shops (within existing estates), high rental accommodation and offices. Some of the high rental properties are either financed by the corporation or jointly by the corporations and corporate developers in those areas which include Ikoyi, Victoria Island and Ikeja (MKO Garden).

Apart from the development of estates, the LSDPC had at various times served as consultants to the State Government on all aspects of the construction of industries and had been able to save millions of Naira through these services for the State Government. As an agent of the government, the corporation designed and supervises the construction of roads and drains in Victoria Island, Oshodi - Apapa Expressway, Ikorodu-Itokin Road which include construction of bridges and large section of roads made with concrete deck on piles in areas with peat formation.

The corporation has to its credit from 1980 till date the following estates in the low and medium income categories of 4,6 , and 8 flats in a block and duplexes for high income groups.

\subsection{Lagos Building Investment Company (LBIC)}

The Lagos Building Investment Corporation was created out of the present Lagos State Development and Property Corporation (LSDPC) in 1982 by the State Government thereby divesting the latter of its investment and Mortgage divisions, in order to promote house ownership and rented housing programmes in the State. It is the state government's agency for providing the needed loan at reasonable rates and long amortization period.

The LBIC provides finance for members of the public who are purchasing low cost houses constructed by the LSDPC. As a great motivation in the provision of houses for the people, the state government has been providing funds to the LBIC and proposed to release annually amounts between N30-N45 million for the 8 years period starting from 1990 to 1998 for the construction of low incomes houses to the LSDPC (the amount have since been reviewed upward). The houses on completion would be passed to the LBIC for allocation to depositors who have been maintaining savings account with LBIC for at least one year.

\subsection{Private Sector Contributions in Housing Development}

Organized private or corporate estate developers are incorporated organizations or companies (bodies recognized by statutes), which are set-up to carry out the development of landed properties. Example of Corporate Estate Developers that abound in Lagos State include, HFP Engineering Company Limited, Cornerstone Construction Company Limited, UACN Property Development and Investment Company Plc, Union Home, Countrywide 
Affordable Estates Project (CAFFEP), Chief Adediran Ajao Company Limited, Crown Realities Plc, Danny Estate etc.

Housing Development is embarked upon by Estate Developers for certain reason or combination of reasons such as: self occupation, social purposes, investment, prestige, political and speculative purposes. The activities of private estate developers can be classified under the following categories:

(a) Private layout as prepared by families and companies that have large expanses of land for housing development such as Ajao, Ashamu, Elemo, Oniru and Ikate families.

(b) Housing scheme such as Shonibare Estate, Ire-Akari Estate, Odutola Estate, Dideolu Estate, Cornerstone Estate, Victoria Garden City (VGC), etc.

(c) Residential Houses built after securing approval of building plans from relevant authorities in the case of small landholdings.

The directives that were given in the 70s to employers of labour throughout the country who are having more than 500 workers to provide housing for their workers also serve as another avenue for housing development through corporate organization. By this, institutions such as Central Bank, First Bank, National Bank, NNPC, Agip etc. built residential estates for their different categories of workers at Satellite Town along Lagos Badagry expressway. Recently, Chevron and Mobil also constructed residential estates along Epe - Lagos expressway (Lekki \& Ajah) to accommodate some of their staff.

In Lagos State private estate development scheme was initiated in August 1988, although a Town \& Country Planning Private Estate Development Regulations had been enacted in 1986. In 1990, the government re-organized the impact of private estate developers in housing delivery. The State Government recognizes the following categories of development programmes to be adopted by private developers.

(a) Comprehensive Land Development Programme: This will involve the provision of a complete range of facilities in addition to the construction of the houses. Essentially, this will include; the preparation of the perimeter survey, layouts and demarcation of the plots on the allocated parcels of land and the provision of other infrastructural facilities as pipe-borne water from the public mains, or estate boreholes, electricity, tarred roads, savage treatment etc.

(b) Limited layout scheme; whereby the developers undertake only perimeter survey, layout demarcation of the plots and provision of earth roads and functional drainage.

(c) Comprehensive site and service scheme: under which all other infrastructural facilities are provided without the actual construction of housing units.

Apart from the self fulfillment enjoyed in housing provision, housing supplies in the private sector are moved by profit motive. As long as the private builder and land speculators provide over 80 percent of housing and also saw an unfulfilled housing demand and a good profit in urban housing, majority of house renters in the cities would be priced out of the housing market and would be forced to spend more than 30 percent of their income on housing services. It was the realization of this profit motive that initially prompted government intervention in housing. However, with the new reality that housing requires a lot of investment, the government is already shifting base by stating emphatically that nobody should expect it to build houses for individual to take over. In essence, a greater role on private participation is essential. The government seems to have reneged on its role that is state under the fundamental economic objectives and directive principles of state policy in section 16(2)(d) of the Constitution that "the State shall direct its policy towards ensuring that suitable and adequate shelter... are provided for all citizens".

\section{Land Law and Housing Provisions in Lagos}

Although compensation is enshrined in the Land Use Act, delay in payment of compensation or resettlement of a displaced person is another serious problem of land acquisition facing the person whose right of occupancy has been revoked. When occasionally compensation is paid, it is hardly adequate. Finally, displaced persons are in most cases resettled in places without the required conveniences or comfort enjoyed in the previous property revoked. Original landowners may occasionally resist the acquisition of their land, which is resulting in delay in the take off of most housing projects. The Cornerstone Construction Company Limited is used to acquiring land for housing project by private treaty.

Suitable lands for housing developments are not readily available at the appropriate locations. It is difficult to know the true occupiers of land in spite of the Land Use Act. There are many fraudulent persons and land speculators defrauding innocent purchases to stultify development as a result of litigations. It is always an up-hill 
task to get a parcel of land hitch-free and the length of time to secure the governor's consent with administrative bottle-neck have been constituting hindrance to developments.

\section{Summary of Findings}

It has been noted that land is the main component of housing problem in urban areas. The problems surrounding availability of land in urban areas have been identified and some of them are set out below:

i. Various policies and regulations that were formulated by governments at all levels to tackle the problems of housing have not provided the required solution to housing deficiency in the country.

ii. The fees payable and the procedure of obtaining Certificate of Occupancy and the Governor's consent is about $15 \%$ and in areas it is up to $45 \%$ of the cost of the land purchased. This creates a problem in housing delivery especially if these documents are required to secure financial assistance from banks. It also leaves room for fraud and compromise. The long time it takes to obtain consent (from six months to eternity) has made reliance on properties as collateral security for loans quite unattractive, as the process of perfecting a legal mortgage is cumbersome.

iii. Most housing programmes implemented by Public Housing Corporation have only benefited the high and medium income groups to the detriment of the low-income earners.

iv. Private estate developers that have taken up the initiatives for housing development have only succeeded in creating expensive residential estates due to high cost of construction, that are not affordable by low-income earners.

v. The present land policy in the country is faced with many problems that make land acquisition difficult for corporate estate developers.

vi. High interest rates have not made procurement of capital for housing development through mortgage finance attractive to developers.

vii. There is no special assistance or grants available presently to developers from government or philanthropists that could serve as incentives to corporate estate developers for the provision of affordable houses which can meet the need of low income groups.

viii. The short period of amortization of loan from financial institutions does not provide low income earners opportunity to take loans for the acquisition of their own houses from the residential estates built by estate developers.

ix. Most building materials such as cement, electrical fittings, sanitary wares etc. are being imported with very high exchange rate resulting in high cost of houses in the face of declining value of Nigeria.

x. The current design of residential estates which are bogus, expensive and cost ineffective does not consider the way of life, the economic means and ability of the low income earners.

xi. The locations of most of the existing estates are too far from the places of work. The residents therefore, spend more on transport fare to commute everyday to their various places of work.

xii. Non-implementation of planning laws and regulations in the country has not allowed the formulation of development plans, make development control difficult and speedy processing of building plans and approvals unrealizable.

xiii. Lack of even distribution of basic infrastructural facilities such as water, road, electricity etc. do not allow for proper development of many residential estates.

\section{Conclusion}

From the foregoing, the Land Use Act has not succeeded in making land readily available to Nigerians because the process of accessibility to land is long, tortuous and expensive. Allocation of land by the Government is selective and cases of speculators who hoard land making it expensive abound. The efforts of the public and the private sectors at ameliorating the shortage of affordable housing for the low income earners have not produced significant strategies for solving the housing problems in our urban centres. In the past few years, the Nigerian economy has witnessed serious macro economic problems characterized by slow down in economic activities, low capital utilization, growing accelerated inflation, intensified exchange rate depreciation as well as high and perversed regime of interest rates. High interest rates have not made procurement of capital for housing development through mortgage finance attractive to developers. 
However, in order to make substantial in roads in the provision of affordable house for low income group of the society, there is a need for a system of careful policy formulation and planning in terms of the character, structure, location or neighbourhood of such housing which will enhance the performance of the corporate estate developer. There is need for an enabling law making it mandatory that houses built for the low income group should be occupied strictly by the people of the class. All applicants should make proof and defaulters should be highly penalized.

\section{References}

Aluko, Ola. (2009). The role of the professionals in the built environment, in Aluko, Ola Editor (Eds.), Introductory Course in Environmental Sciences. Ibadan: Kins.

Aluko, Ola. (2007). Renal Sub-sector and Housing Delivery System in Nigeria a paper presented at the National Workshop on Private Sector Driven Housing Delivery; Issues, Constraints, Challenges and Prospects organized by University of Lagos, Department of Estate Management in collaboration with Real Estate Developers Association of Nigeria (REDAN), at Main Auditorium, University of Lagos, between (July 30-31).

Aluko, Ola. (2010). Housing Provision and Development in Nigeria: The Dashed Hope of the poor, paper presented at the National Conference and Exhibition on Challenges of Sheller and Environment for Nigeria in the coming Decades (CEENACON) organized by College of Engineering and Environmental Sciences, Imo State University, Owerri (April 6-9).

Ayeni, M. A. O. (1991). The Growth and Development of Metropolitan Lagos, Seminar on the Effects of Lagos on the Movement of the Federal Capital to Abuja (November 21-22).

Mabogunje A. L. (2007). Developing Mega Cities in Developing Countries, being text of a lecture delivered at a Colloquim organized by the 2007 Graduating Class, Department of Geography, University of Lagos on Wednesday (September 12).

Mabogunje, Akin L. (2011). Promoting Good Governance: What Can We, The People, Do? Paper presented at 4th Anniversary Public Lecture of the splash 105.5 FM, Ibadan on Friday (July 8).

Megbolugbe, I. F. (1983). The Hopes and Failures of Public Housing. Third World Planning Review, 5, 4.

Onibokun, Poju. (1990). The Urban Setting in Nigeria, in Onibokun, Poju Editor (Ed.), Urban Housing in Nigeria. Ibadan: NISER.

Onibokun, Poju. (1985). Public Housing Delivery System in Nigeria (1979-1983): A Critical Review, in Onibokun, Poju Editor (Ed.), Housing in Nigeria (pp. 429-446). Ibadan: NISER.

Oduniyi, J. T. B. (1981). Land Use Decree, 1978: Case Study, in Igbozurike, U. M. Editor (Ed.), Land Use and Conservation in Nigeria (pp.16 - 20). Nsukka: University of Nigeria Press.

Tobi, N. (1997). Cases and Materials on Nigerian Land Law (pp. 1 - 49). Mabochi Books.

Udo, R. K. (1990). Land Use Policy and Land Ownership in Nigeria (pp. 103). Lagos: Ebieakwa Ventures. 
Table 1. Residential estate developed by LSDPC

Low income category

\begin{tabular}{|c|c|c|c|}
\hline Location of Scheme & 2-Bedroom & 3 -Bedroom & Total No of Units \\
\hline Abesan & 348 & 4,044 & 4,392 \\
Abulenla & - & 90 & 90 \\
Agarawu & - & 18 & 18 \\
Akerele & - & 18 & 18 \\
Amuwo Odofin & 1,540 & 1,428 & 714 \\
Anikantamo & 90 & 624 & 78 \\
Badagry & - & 78 & 36 \\
Bank Olemoh & - & 36 & 708 \\
Ijaiye (Diary farm) & - & 708 & 60 \\
Epe & - & 60 & 2,388 \\
Iba & - & 2,388 & 464 \\
Ije (Dolphin) & 120 & 344 & 78 \\
Ikorodu & - & 78 & 1,026 \\
Iponri & 624 & 402 & 3,764 \\
Isolo & 1,292 & 2,472 & 42 \\
Itire & - & 42 & 30 \\
Lawanson & - & 30 & 48 \\
Oko-awo & - & 48 & 540 \\
Ojokoro Phase I & - & 540 & 438 \\
Ojokoro Phase II & 168 & 270 & 22 \\
Surulere & - & 22 & 17,922 \\
\hline Total & 4,182 & 13,740 & \\
\hline
\end{tabular}

Medium income: a block of a 4 (no) 4 bedroom flat

\begin{tabular}{|c|c|}
\hline Location & No of Units \\
\hline Alapere & 152 Units \\
Alaka & 16 Units \\
Opebi & 140 Units \\
Ogba Phase I & 28 Units \\
Ogba Phase II & 56 Units \\
Omole & 100 Units \\
Amuwo-Odofin & 36 Units \\
Ijaiye Phase I & 512 Units \\
Ijaiye (Type 4C) & 280 Units \\
Ijaiye Semi Detached Bungalows & 12 Units \\
Ebute-Metta (Herbert Macaulay) & 528 Units \\
\end{tabular}

High income projects

\begin{tabular}{|c|c|}
\hline Location & No of Duplexes \\
\hline Ojota/Ogudu Phase I & 102 Duplexes (4 Bedroom) \\
Ojota/Ogudu Phase I Extension & 24 “ \\
Amuwo-Odofin Phase I & 100 “ \\
Dolphin Phase I & 658 “" \\
\hline
\end{tabular}

Source: Lagos state development and property corporation publication, May, 2010 